\title{
Analisis Model Atas Faktor Penentu Nilai Perusahaan (Studi Pada Perusahaan Pulp and Paper yang Terdaftar di BEI 2015-2019)
}

\author{
William Fernando ${ }^{*}$, Temy Setiawan² \\ 1, 2 Universitas Bunda Mulia \\ 1'wfernando35@gmail.com; ${ }^{2}$ operasionaltemysetiawan@gmail.com \\ ${ }^{*}$ Penulis korespondensi
}

\begin{abstract}
This study aims to analyze the factors that influence firm value, where the independent variables consist of ownership structure, capital structure and gender diversity, and financial performance as a mediation. The research used is Pulp \& Paper companies listed on the Indonesia Stock Exchange for the period 2015 - 2019. Using samples from 7 manufacturing companies. By using a sample of 7 manufacturing companies. The test analysis used is the SmartPLS 3.0 program. Based on the results of the study, ownership structure and gender diversity have no significant effect on firm value, capital structure and financial performance have a significant positive effect on firm value, and financial performance has no significant effect on mediating ownership structure and capital structure on the firm. The limitation of this study is to use financial reports sourced from the Indonesia Stock Exchange (IDX) for the pulp and paper sector from 2015-2019 and have financial reports for 5 consecutive years. The implications of this research are expected to provide information for investors on things that can affect the value of the company, especially the paper industry sector.
\end{abstract}

Keywords: ownership structure, capital structure, gender diversity, firm value and financial performance

\begin{abstract}
Abstrak
Penelitian ini bertujuan untuk menganalisis faktor-faktor yang mempengaruhi nilai perusahaan, dimana variabel independen terdiri dari struktur kepemilikan, struktur modal dan keragaman gender, dan kinerja keuangan sebagai mediasi. Penelitian yang digunakan adalah perusahaan Pulp \& Paper yang terdaftar di Bursa Efek Indonesia periode 2015 - 2019. Dengan menggunakan sampel dari 7 perusahaan manufaktur. Analisis pengujian yang digunakan adalah program SmartPLS 3.0. Berdasarkan hasil penelitian, struktur kepemilikan dan keragaman gender tidak berpengaruh signifikan terhadap nilai perusahaan, struktur modal dan kinerja keuangan berpengaruh signifikan positif terhadap nilai perusahaan, dan kinerja keuagan tidak berpengaruh signifikan memediasi struktur kepemilikan dan struktur modal terhadap nilai perusahaan. Batasan dalam penelitian ini yaitu dengan menggunakan laporan keuangan yang bersumber dari Bursa Efek Indonesia (BEI) sektor pulp and paper mulai dari 2015-2019 dan memiliki laporan keuangan 5 tahun berturut. Implikasi pada penelitian ini diharapkan dapat memberikan informasi bagi investor hal yang dapat mempengaruhi nilai perusahaan khususnya sektor industri kertas.
\end{abstract}

Kata Kunci: struktur kepemilikan, struktur modal, keragaman gender, nilai perusahaan dan kinerja keuangan 


\section{PENDAHULUAN}

Tujuan dari setiap perusahaan adalah untuk meraih keuntungan setinggi mungkin sehingga dapat menarik perhatian para investor yang secara langsung dapat meningkatkan nilai perusahaan. Nilai perusahaan yang tinggi menunjukan tingginya minat investor terhadap perusahaan tersebut. Menurut Kontesa (2015) nilai perusahaan merupakan keseluruhan dari total ekuitas dan liabilitas yang sering disebut juga sebagai nilai pasar atau nilai perusahaan. Brigham (2019) menyatakan tingginya harga saham akan dapat meningkatkan nilai perusahaan juga. Kesejahteraan pemangku kepentingan dapat terlihat dari nilai perusahaan yang baik.

Sukirno (2020) menyatakan pasar modal Indonesia terburuk di dunia pada 2019 menyatakan, IHSG di Indonesia hanya bertumbuh sebesar 1,7\% dan berada di peringkat ke 31 dari 36 bursa utama sepanjang tahun 2019. Inarno Djajadi selaku Direktur Utama Bursa Efek di Indonesia menyatakan, 2019 adalah tahun penuh tantangan yang dapat berpengaruh terhadap kinerja perusahaan yang tercatat dalam bursa efek. Setiap perusahaan bertujuan untuk meningkatkan kesejahteraan pemegang saham, salah satu caranya yaitu dengan meningkatkan nilai perusahaan. Kontesa (2015) menyebutkan nilai perusahaan sangatlah penting karena nilai perusahaan mencerminkan kinerja pasar dari perusahaan tersebut dan kinerja pasar tersebut yang mempengaruhi pandangan investor terhadap perusahaan. Karena hal tersebut maka penting untuk investor agar dapat menganalisa pengaruh apa saja yang akan berpengaruh terhadap nilai perusahaan. Beberapa hal yang dapat berpengaruh terhadap corporate value antara lain ownership structure, capital structure, dan juga gender diversity.

Wayat et al. (2019) menyimpulkan struktur kepemilikan merupakan peran dari pemegang saham atau pemangku kepentingan perusahaan dalam mengawasi perusahaannya. Struktur kepemilikan dipercaya dapat berpengaruh pada berjalannya suatu perusahaan sehingga dapat meningkatkan kinerja maupun nilai perusahaan. Menurut Made dan Luh (2020) menyatakan struktur kepemilikan merupakan pembagian kepemilikan dalam suatu perusahaan yang dimana dalam pemangku kepentingan perusahaan terdiri dari kepemilikan asing, kepemilikan manajerial dan kepemilikan institusi. Dalam penelitian Wayan et al. (2020) menyatakan struktur kepemilikan memiliki pengaruh negatif yang signifikan terhadap nilai perusahaan, dan kinerja keuangan pengaruh signifikan positif signifikan memediasi pengaruh dari struktur kepemilikan pada nilai perusahaan. Namun berlawanan dengan penelitian Aymen (2014) yang menyatakan kinerja keuangan tidak terpengaruh secara signifikan dari struktur kepemilikan.

Kontesa (2015) menyatakan rasio leverage merupakan bagian dari pendanaan hutang perusahaan dalam struktur modal. Hutang juga sebagai salah satu bagian struktur modal perusahaan. Struktur modal merupakan hal penting dalam peningkatan produktivitas dan kinerja dalam perusahaan. Menurut Kontesa (2015) teori struktur modal menarangkan kebijakan pendanaan digunakan untuk menentukan struktur modal perusahaan yang dapat digunakan untuk mengoptimalkan nilai perusahaan. Struktur modal perusahaan yang optimal yaitu perpaduan dari hutang dan modal yang dapat memaksimalkan harga 
saham pada perusahaan. Pernyataan yang sama diungkapkan oleh Shinta et al. (2014) dalam penelitiannya disebutkan struktur modal merupakan proporsi pembiayaan ekuitas dan pembiayaan hutang dalam suatu perusahaan. Dalam penelitian Kontesa (2015) menyebutkan struktur modal signifikan berpengaruh positif terhadap nilai perusahaan. Pernyataan tersebut didukung juga oleh Shinta et al. (2014) bahwa struktur modal memiliki pengaruh yang signifikan terhadap nilai perusahaan.

Menurut Ullah et al. (2019) menyatakan keragaman gender diidentifikasikan sebagai hal penting bertujuan dalam mendorong mekanisme pemantauan. Dalam penelitian Ullah et al. (2019) disampaikan bahwa hubungan antara keragaman gender dewan dan nilai perusahaan umumnya dibahas dalam kerangka teori agensi, dimana hal tersebut menyoroti fungsi dari pemantauan dewan yang dengan keragaman gender. Menurut Ullah et al. (2019) sangat penting dalam perusahaan untuk meningkatkan proporsi direktur perempuan di dewan yang dapat membuat tata kelola perusahaan yang lebih baik, dengan mengurangi terjadinya konflik keagenan dan meningkatkan nilai perusahaan. Dalam penelitian Peter dan Hannu (2019) menyatakan kergaman gender memilikiki hubungan yang signifikan terhadap nilai perusahaan. Hal tersebut didukung juga dalam penelitian Ullah et al. (2019) yang menyebutkan bahwa keragaman gender signifikan positif mempengaruhi nilai perusahaan.

Wayan et al. (2020) menyebutkan kinerja keuangan adalah pengukuran untuk melihat seberapa besar kemampuan perusahaan dapat menciptakan laba. Menurut Van Horne dan Wachowicz (2005) dalam penelitian Wayan et al. (2020) ada beberapa rasio pengukuran kinerja keuangan, yaitu; (1) ROA yang diukur dari net profit dari total asset. Nilai ROA yang tinggi menunjukkan kinerja keuangan perusahaan yang lebih baik. Karena tingkat pengembalian investasi yang lebih besar; (2) ROE diukur dengan membandingkan jumlah net profit dari ekuitas. nilai ROE yang tinggi menunjukkan tingkat efisien perusahaan dalam penggunaan modal juga lebih baik sendiri untuk menghasilkan keuntungan investor yang ditanamkan dalam perusahaan.

Pada penelitian ini berupaya menjembatani adanya perbedaan dari berbagai penelitian (research gap) terhadap penelitan terdahulu, yang membedakannya yaitu adanya perbedaan pada sub sektor yang diteliti, perbedaan kedua terdapat pada tahun yang diteliti yang pada penelitian terdahulu dari tahun 2010 - 2019 dan pada penelitian ini menggunakan tahun 2015 - 2019, dan perbedaan selanjutnya terletak pada variabel independen yang mempengaruhi, pada penelitian ini penulis menggunakan struktur kepemilikan, struktur modal, dan keragaman gender sebagai variabel independen.

Motivasi peneliti dalam mengangkat topik penelitian ini adalah karena hasil penelitian terdahulu yang tidak konsisten dimana dalam pengujian terdahulu ditemukan adanya pengaruh positif dan negatif bahkan tidak berpengaruh, maka penelitian ini perlu dilakukan untuk meneliti kembali pengaruh struktur kepemilikan, struktur modal, dan keragaman gender terhadap nilai perusahaan yang dimediasi oleh kinerja keuangan pada sektor Pulp \& Paper yang terdaftar di Bursa Efek Indonesia (BEI) pada periode 2015 sampai dengan 2019.

Perusahaan Pulp \& Paper merupakan perusahaan yang memproduksi berbagai macam jenis kertas untuk memenuhi kebutuhan masyarakat, dimana kertas tersebut dapat digunakan 
untuk buku tulis, packaging, kalender, bungkus makanan, keperluan rumah tangga dan masih banyak lainnya. Tri A. (2019), dalam Harian Kontan menyebutkan Industri pulp \& paper cukup signifikan berkontribusi bagi perekonomian di Indonesia. Asosiasi Pulp \& Paper Indonesia (APKI) menilai adanya peningkatan sebesar $2 \%$ atas permintaan baik secara lokal maupun internasional. Saat ini, produksi pulp di Indonesia berkapasitas 11 juta ton per tahun dan memproduksi 16 juta ton kertas per tahun. Pada 2018, industri pulp \& paper berkontribusi 17,6\% terhadap industri non-migas dan 6,3\% terhadap industri pengolahan nasional. Industri pulp \& paper diperkirakan akan dapat bertumbuh sebesar $5 \%$ pada tahun 2019. Indonesia merupakan urutan ke 9 untuk penggunaan pulp di dunia serta urutan ke 6 untuk penggunaan kertas di dunia. Disisi tenaga kerja, industri pulp \& paper terdapat 260.000 tenaga kerja langsung dan 1,1 juta tenaga kerja tidak langsung. Secara tidak langsung, industri pulp \& paper merupakan sektor padat karya dan berorientasi ekspor. CNBC Indonesia juga menyebutkan salah satu pendorong kenaikan IHSG adalah melonjaknya harga saham kertas dari PT Pabrik Kertas Tjiwi Kimia Tbk (TKIM) sebesar 16,4\% dan PT Indah Kiat Pulp and Paper Tbk (INKP) sebesar 13,6\%.

Larangan penggunaan plastik di Indonesia menyebabkan kinerja keuangan pada perusahaan-perusahaan kertas di Indonesia meningkat, dimana hal tersebut terjadi karena perpindahan pengguna plastik menjadi kertas seperti kertas daur ulang yang dibuat menjadi paper bag, dan juga paper lunch box sehingga mengurangi limbah plastik. Terlihat pada kinerja dari beberapa perusahaan kertas yang meningkat sejak 2014 hingga 2018 pada PT INKP, seperti pada informasi berikut ini:

Gambar 1 Rasio Keuangan INKP

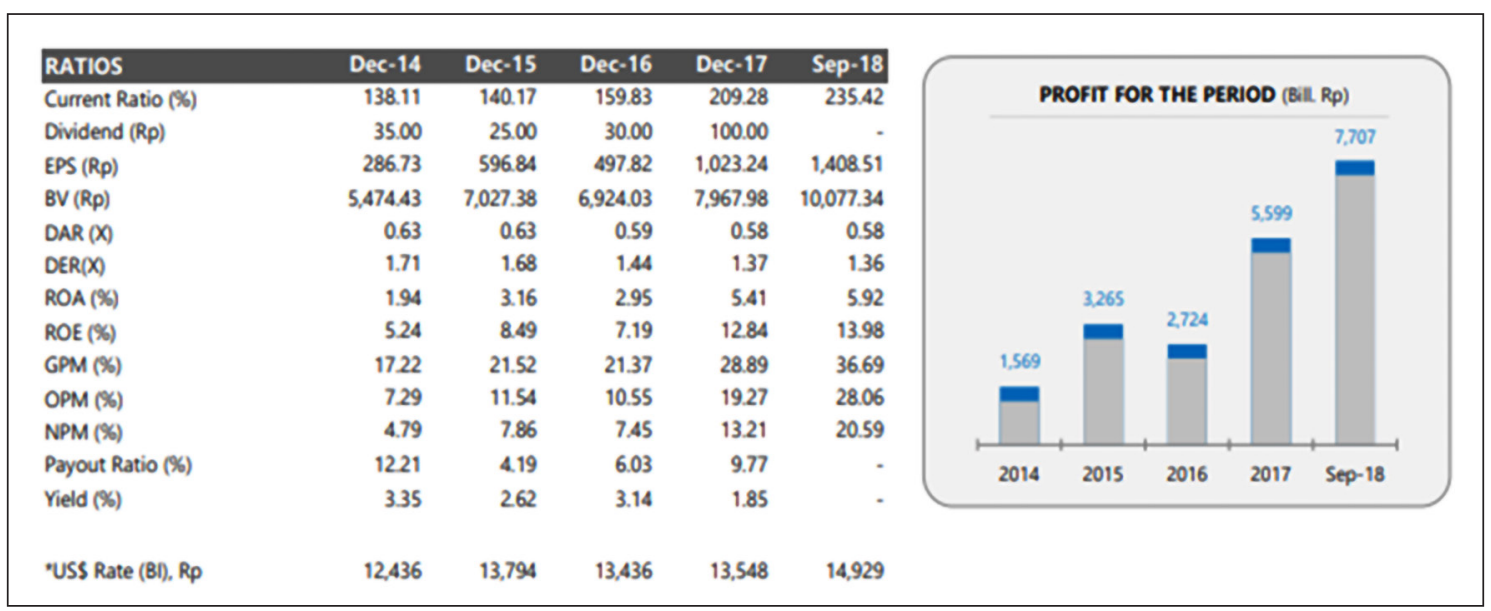

Sumber: https://www.idx.co.id/data-pasar/laporan-statistik/ringkasan-performa-perusahaan-tercatat/

Terlihat pada rasio keuangan perusahaan kertas INKP dimana ROE dan ROA menunjukan peningkatan sejak tahun 2014. Peningkatkan kinerka keuangan tersebut menunjukan perkembangan kertas di Indonesia yang terus meningkat setiap tahunnya terutama pada sektor makanan dan kantong belanja. Banyak tempat makan yang sudah beralih dari kantong plastik menjadi paper bag dan banyak makanan yang sudah dikemas dengan paper lunch box. Tingginya tingkat penggunaan kertas menyebabkan perusahaan kertas 
cukup mengalami overload sehingga hal tersebut menjadi peluang bagi perusahaan baru untuk bergerak dibidang pulp \& paper.

Wayan et al. (2020) dan Syamsudin (2019) menyebutkan bahwa adanya pengaruh negatif antara struktur kepemilikan terhadap nilai perusahaan yang diukur dari struktur kepemilikan, lokal atau asing, dan peredaran saham. Disisi lain, Vintila (2014) menyebutkan adanya pengaruh signifikan positif antara konsentrasi kepemilikan terhadap nilai perusahaan. Dalam hubungannya dengan kinerja keuangan, pengaruh kepemilikan ditemukan memberikan dampak positif terhadap kinerja perusahaan Wayan et al. (2020). Sugosha dan Artini (2020) menyebutkan bahwa profitabilitas mampu memediasi pengaruh kepemilikan asing terhadap nilai perusahaan namun tidak dapat memediasi kepemilikan institusional dan kepemilikan manajerial terhadap nilai perusahaan. Disisi lain, Hasanudin et al. (2020) yang menyatakan bahwa kinerja keuangan mampu memediasi pengaruh kepemilikan institusional terhadap nilai perusahaan.

Selain struktur kepemilikan, struktur modal menentukan nilai perusahaan, Pengaruh struktur modal ditemukan berdampak negatif terhadap nilai perusahaan mengingat peningkatan hutang akan berdampak negatif bagi nilai perusahaan (Manurung 2014; Wayan et al. 2020). Maria (2014) menunjukkan hasil yang berbeda dengan menyatakan bahwa DER berpengaruh positif terhadap nilai perusahaan yang berarti meningkatnya hutang juga akan meningkatkan kegiatan penjualan dan memperoleh laba yang lebih besar sehingga meningkatkan nilai perusahaan. Dalam hubungannya dengan kinerja keuangan, Ardi et al. (2016) menyebutkan bahwa DER berpengaruh signifikan negatif terhadap ROE. Hasil tersebut didukung juga dalam penelitian yang dilakukan Maria (2014) yang menyebutkan bahwa struktur modal berpengaruh negatif terhadap profitabilitas. Hal ini menunjukan dengan meningkatnya hutang dalam perusahaan dapat membuat kinerja keuangan kearah negatif. Namun bertentangan dengan hasil penelitian yang dilakukan Wayan et al. (2020) yang menyebutkan bahwa struktur modal berpengaruh positif terhadap kinerja keuangan.

Keragaman gender ditemukan dalam beberapa penelitian. Agyemang (2019) menyebutkan bahwa keragaman gender berpengaruh positif terhadap nilai perusahaan hal ini ditunjukkan dengan pengambilan keputusan dapat dipandang dari laki-laki dan perempuan yang membuat penilaian lebih baik sehingga dapat meningkatkan nilai perusahaan. Penelitian serupa dilakukan Ullah (2019) yang menyebutkan adanya pengaruh signifikan yang positif antara direktur perempuan di perusahaan dengan nilai perusahaan. Disisi lain, Fidanoski (2014) yang menyebutkan bahwa Women on Board Ratio berpengaruh negatif.

Berdasarkan uraian tersebut, maka hipotesis untuk penelitian ini adalah:

H1: Struktur kepemilikan, struktur modal yang dimediasi oleh kinerja keuangan perusahaan, dan keragaman gender berpengaruh positif terhadap nilai perusahaan.

\section{METODE}

Menurut Sekaran dan Bougie (2016), desain penelitian dibuat untuk memperoleh jawaban dari masalah yang ada dengan mengumpulkan, menganalisis dan menafsirkan data lebih lanjut. Penelitian ini merupakan pengujian yang menjelaskan dari hipotesis dari 
pengaruh struktur kepemimpinan, struktur modal, dan keragaman gender terhadap nilai perusahaan yang dimediasi oleh kinerja keuangan. Menurut Sekaran dan Bougie (2016), Pendekatan penelitian positivistik merupakan pendekatan penelitian yang dapat diukur dan diamati secara objektif untuk menguji hubungannya dengan menggunakan desain penelitian. Penelitian ini melakukan pengujian secara kuantitatif dimana menggunakan pendekatan penelitian secara positivistik untuk menguji objek yang ada. Dalam penelitian ini penulis menggunakan data panel untuk melakukan penelitian. Data panel merupakan data pengamatan yang dilakukan dari waktu ke waktu.

\section{Teknik Analisis}

1. Uji Validitas

Suatu indikator dinyatakan valid jika mempunyai nilai loading factor diatas 0,7 terhadap variabel yang dituju maka dapat dinyatakan valid.

2. Discriminant Validity (Cross Loading)

Suatu indikator dinyatakan valid jika mempunyai loading factor tertinggi kepada konstruk yang dituju dibandingkan dengan loading factor kepada konstruk lain dan menunjukan nilai loading factor diatas 0,7 terhadap variabel yang dituju maka dapat dinyatakan valid.

3. Outer Model

Dalam outer model digunakan 3 pengujian yaitu AVE (Average Vvariabel Eror), Composite Reliability, dan Cronbach's Alpha. Pada pengujian AVE, nilai yang disarankan adalah diatas 0,5 dan dinyatakan valid. Dalam pengujian Composite Reliability, dan Cronbach's Alpha dapat dinyatakan reliable apabila nilai factor loading diatas 0,7.

4. Inner Model

Merupakan uji kecocokan model untuk melihat suatu model tersebut dapat dinyatakan baik. Dalam penilaian dinyatakan good fit jika memenuhi standar $\mathrm{P}<0,05$, dinyatakan marginal fit jika tidak memenuhi standar, dan dinyatakan poor fit jika jauh memenuhi standar.

5. Uji Hipotesis

Dalam pengujian hipotesis dapat dinyatakan signifikan jika dalam pengujian T-Statistik menunjukan nilai diatas 1,96 dan dapat dinyatakan signifikan positif apabila nilainya positif dan signifikan negatif apabila nilainya menunjukan negatif dan dinyatakan tidak signifikan jika nilai dibawah 1,96. Pada pengujian hipotesis juga dilakukan dengan menguji $P$-value dimana hipotesis dinyatakan berpengaruh signifikan apabila nilai $p$-value lebih kecil atau sama dengan 0,05. Dalam pengujian hipotesis digunakan dua pengujian yaitu direct effect dan indirect effect. 


\section{HASIL DAN PEMBAHASAN}

Berikut ini disajikan hasil penelitian yang diperoleh:

Tabel 1 Hasil Uji Path Coefficient

\begin{tabular}{|c|c|c|c|c|c|}
\hline & $\begin{array}{c}\text { Original } \\
\text { Sample (0) }\end{array}$ & $\begin{array}{c}\text { Sample } \\
\text { Mean (M) }\end{array}$ & $\begin{array}{l}\text { Std. Deviation } \\
\text { (STDEV) }\end{array}$ & $\begin{array}{l}\text { T Statistics } \\
(\mid 0 / \text { STDEV } \mid)\end{array}$ & $\begin{array}{c}\mathbf{P} \\
\text { Values }\end{array}$ \\
\hline Keragaman gender $\rightarrow$ Nilai Perusahaan & 0.119 & 0.088 & 0.187 & 0.634 & 0.526 \\
\hline Kinerja Keuangan $\rightarrow$ Nilai Perusahaan & 0.767 & 0.769 & 0.145 & 5.283 & 0.000 \\
\hline Struktur Kepemilikian $\rightarrow$ Kinerja Keuangan & 0.162 & 0.182 & 0.208 & 0.779 & 0.436 \\
\hline Struktur Kepemilikian $\rightarrow$ Nilai Perusahaan & 0.178 & 0.145 & 0.205 & 0.868 & $0 / 386$ \\
\hline Struktur Modal $\rightarrow$ Kinerja Keuangan & -0.317 & -0.318 & 0.225 & 1.408 & 0.160 \\
\hline Struktur Modal $\rightarrow$ Nilai Perusahaan & 0.345 & 0.327 & 0.169 & 2.045 & 0.041 \\
\hline
\end{tabular}

Sumber: data yang diolah

Tabel 2 Hasil Uji Specifict Indirect Effects

\begin{tabular}{|c|c|c|c|c|c|}
\hline & $\begin{array}{c}\text { Original } \\
\text { Sample (0) }\end{array}$ & $\begin{array}{c}\text { Sample } \\
\text { Mean (M) }\end{array}$ & $\begin{array}{l}\text { Std. Deviation } \\
\text { (STDEV) }\end{array}$ & $\begin{array}{l}\text { T Statistics } \\
(\mid 0 / \text { STDEV } \mid)\end{array}$ & $\begin{array}{c}\mathbf{P} \\
\text { Values }\end{array}$ \\
\hline $\begin{array}{l}\text { Struktur Modal } \rightarrow \text { Kinerja Keuangan } \rightarrow \\
\text { Nilai Perusahaan }\end{array}$ & -0.244 & -0.241 & 0.172 & 1.417 & 0.157 \\
\hline $\begin{array}{l}\text { Struktur Kepemilikan } \rightarrow \text { Kinerja Keuangan } \rightarrow \\
\text { Nilai Perusahaan }\end{array}$ & 0.125 & 0.143 & 0.165 & 0.757 & 0.449 \\
\hline
\end{tabular}

Sumber: data yang diolah

Analisis data menunjukkan bahwa struktur kepemilikan dan keragaman gender tidak mempengaruhi nilai perusahaan. Hal ini didukung oleh hasil analisis yang menyatakan nilai signifikansi $>0,05$. Hasil ini sejalan dengan teori struktur kepemilikan Ferina (2014) yang menyatakan bahwa struktur kepemilikan tidak berpengaruh terhadap nilai perusahaan. Namun penelitian ini bertolak belakang dengan teori keragaman gender Fidanoski (2014) yang menyatakan bahwa keragaman gender berpengaruh signifikan negatif terhadap nilai perusahaan.

Menurut Ferina (2014) struktur kepemilikan sangatlah penting dalam menilai perusahaan. Struktur kepemilikan dianggap sangatlah penting bagi perusahaan karena struktur kepemilikan dapat mempengaruhi kinerja keuangan dalam proses memaksimalkan nilai perusahaan dengan meningkatkan kegiatan operasional. Dan Agyemang (2019) keragaman gender merupakan perpaduan antara laki-laki dan perempuan dalam dewan perusahaan yang bertujuan untuk menyeimbangkan pendapat ataupun pandangan yang berbeda yang dapan meningkatkan kinerja keuangan perusahaan. Namun dalam penelitian ini menunjukan struktur kepemilikan dan keragaman gender tidak berpengaruh terhadap kinerja keuangan dan tidak berpengaruh terhadap nilai perusahaan. Kondisi ini terjadi karena dalam perusahaan sub sektor pulp \& paper tidak terlalu mementingkan siapa saja pemegang sahamnya karena siapapun pemegang saham tersebut tidak mempengaruh kegiatan operasional perusahaannya. Dan juga dalam perusahaan sub sektor pulp \& paper 
siapapun pengambilan kekuasaannya baik laki-laki maupun perempuan tidak mempengaruhi kegiatan operasional.

Analisis selanjutnya mengenai struktur modal, menunjukkan bahwa struktur modal dan kinerja keuangan berpengaruh terhadap nilai perusahaan. Hal ini didukung oleh hasil analisis yang menyatakan nilai signifikansi $<0,05$. Hasil ini sejalan dengan teori struktur modal Rahayu et al. (2019) yang menyatakan bahwa struktur modal berpengaruh signifikan positif terhadap nilai perusahaan, dimana kinerja keuangan berpengaruh signifikan positif terhadap nilai perusahaan (Kontesa, 2015). Kondisi ini menunjukkan bahwa untuk mendapatkan nilai perusahaan yang baik, perusahaan harus mampu mengelola hutang dan modalnya. Hal ini sejalan dengan penelitian Ross et al. (2019) yang menyatakan semakin tingginya hutang dapat meningkatkan kinerja keuangan yang secara langsung dapat menarik minat para investor sehingga dapat berpengaruh terhadap nilai perusahaan melalui signal yang diberikan perusahaan. Ross et al. (2019) dimana pengaruh kinerja keuangan sebagai mediasi bagi struktur kepemilikan dan struktur modal terhadap nilai perusahan menunjukkan hasil yang berbeda.

Analisis menunjukkan bahwa kinerja keuangan tidak berpengaruh dalam memediasi pengaruh struktur kepemilikan dan struktur modal terhadap nilai perusahaan sebagaimana hasil uji statistik yang menyatakan nilai signifikansi $>0,05$. Hasil ini sejalan dengan teori Kontesa (2015) yang menyatakan bahwa kinerja keuangan tidak berpengaruh terhadap mediasi struktur modal terhadap nilai perusahaan. Hal ini terjadi karena struktur modal dalam sebuah perusahaan dapat memberikan efek yang positif danjuga negatif, dalam hal ini hutang dapat memberikan pengaruh positif jika digunakan untuk memaksimalkan kegiatan operasional namun dengan hutang yang tinggi juga akan dapat menimbulkan pengaruh negatif bagi nilai perusahaan karena dapat dinilai perusahaan akan kesulitan dalam melunasi hutangnya. Sehingga tidak dapat menunjukkan pengaruh terhadap nilai perusahaan ketika kinerja perusahaan menjadi mediasi bagi keduanya. Kondisi ini didukung oleh Hasanudin et al. (2020), dimana Kinerja keuangan merupakan penentuan seberapa efektif kegiatan operasional dalam suatu perusahaan.

Menurut Peran kinerja keuangan sebagai mediasi untuk struktur kepemilikan dan struktur modal menunjukkan hasil.tidak adanya berpengaruh terhadap nilai perusahaan Hal ini menunjukkan bahwa uji statistik yang dilakukan pada penelitian ini dimana uji statistik menunjukkan nilai signifikansi $>0,05$. Kondisi ini dan bertolak belakang dengan teori Artini (2020) yang menyatakan bahwa struktur kepemilikan berpengaruh positif terhadap nilai perusahaan melalui mediasi kinerja keuangan. Hal ini terjadi dikarenakan semakin tingginya tingkat pengembalian tidak dapat memperkuat atau melemahkan hubungan dari struktur kepemilikan dan struktur modal terhadap nilai perusahaan Hasanudin et al. (2020). Berdasar pada diskusi ini, maka nilai perusahaan akan lebih ditentukan oleh kemampuan perusahaan dalam mengelola hutang dan modalnya daripada pemegang saham maupun kinerja perusahaan. 


\section{SIMPULAN}

Penelitian ini bertujuan untuk menunjukan pengaruh dalam menilai perusahaan, pengaruh yang digunakan antara lain struktur kepemilikan, struktur modal, keragaman gender dan kinerja keuangan. Berdasarkan temuan dalam penelitian ini, struktur kepemilikan dan keragaman gender tidak memiliki pengaruh terhadap nilai perusahaan, namun pada struktur modal dan kinerja keuangan berpengaruh terhadap nilai perusahaan. Hal ini menunjukan bahwa investor lebih memperhatikan struktur modal dan kinerja keuangan dalam berinvestasi dibandingkan dengan memperhatikan struktur kepemilikan dan keragaman gender, hal tersebut dapat terjadi karena perpaduan hutang dan ekuitas yang baik dapat meningkatkan kinerja keuangan sehingga akan memberikan tingkat pengembalian dana yang tinggi bagi para investor hal ini secara langsung dapat meningkatkan harga saham yang juga berarti menaikan nilai perusahaan.

Berdasarkan hasil temuan dalam penelitian, saran yang dapat diberikan adalah sebagai berikut: 1). Bagi manajemen dapat mengetahui bahwa struktur kepemilikan, struktur modal dan keragaman gender dapat mempengharuhi nilai perusahaan untuk industri pulp \& paper oleh karena itu, dalam meningkatkan nilai perusahaan maka manajemen harus lebih memperhatikan struktur modal dan kinerja keuangan agar dapat menarik minat para investor. 2). Bagi investor, diharapkan dapat menjadi pertimbangan dalam menilai perusahaan dalam mengambil keputusan untuk berinvestasi. Melihat hasil temuan yang menyatakan bahwa struktur kepemilikan yang tidak berpengaruh baik langsung maupun tidak langsung dapat menjadi pertimbangan bagi investor untuk tidak berpatokan pada struktur kepemilikan dalam menilai perusahaan. Namun dapat menjadi pertimbangan bagi para investor untuk memperhatikan struktur modal suatu perusahaan menjadi salah satu pertimbangan dalam menilai suatu perusahaan. 3). Bagi penelitian selanjutnya, hasil ini diharapkan menjadi pedoman dalam penelitian selanjutnya untuk dikembangkan lagi dengan faktor lainnya yang dapat mempengaruhi nilai perusahaan seperti ukuran perusahaan dan tata kelola perusahaan.

\section{PUSTAKA ACUAN}

Agyemang-Mintah, P., \& Schadewitz, H. 2019. Gender diversity and firm value: evidence from UK financial institutions. International Journal of Accounting \& Information Management.

Alinea.id. (2020, 1 Januari). Pasar modal Indonesia terburuk di dunia pada 2019. Diakses pada 15 Oktober 2020, dari https://www.alinea.id/bisnis/pasar-modal-indonesiaterburuk-di-dunia-pada-2019-b1ZGm9qpg\#: :text=Sampai\%20saat\%20ini\%20jumlah\%20 total,sebanyak\%201\%2C62\%20juta\%20investor

Analisis.kontan.co.id. (2019, 12 Maret). Industri pulp dan kertas Indonesia. Diakses pada 15 Oktober 2020, dari https://analisis.kontan.co.id/news/industri-pulp-dan-kertasindonesia

Aymen, B. M. M. 2014. Impact of ownership structure on financial performance of banks: case of Tunisia. Journal of Applied Finance and Banking, 4(2), 163. 
Brigham, E. F., \& Houston, J. F. 2019. Fundamentals of financial management. Nelson Education.

cnbcindonesia.com (2021, 04 Februari). Saham Kertas \& Baterai Melaju, IHSG Menguat di Closing Sesi 1. Diakses pada 19 April 2021, dari https://www.cnbcindonesia.com/ market/20210204114841-17-220981/saham-kertas-baterai-melaju-ihsg-menguat-diclosing-sesi-1

Demsetz, H. 1983. The structure of ownership and the theory of the firm. The Journal of Law and Economics 26(2), p. 375-390.

Ferina, I. S., \& Nurcahaya, C. 2014. Ownership structure and firm values: empirical study on Indonesia manufacturing listed companies. Researchers World, 5(4), 1.

Fidanoski, F., Simeonovski, K., \& Mateska, V. 2014. The impact of board diversity on corporate performance: New evidence from Southeast Europe. Corporate Governance in the US and Global Settings, 17(2), 81-123.

Gallego-A'lvarez, I., Garcı'a-Sa'nchez, I. M. \& Rodrı'guez-Dominguez, L. 2010. The influence of gender diversity on corporate performance. Revista de Contabilidad. Vol. 13 No. 1, pp. 53-88.

Hasanudin, H., Nurwulandari, A., Adnyana, I. M., \& Loviana, N. 2020. The Effect of Ownership and Financial Performance on Firm Value of Oil and Gas Mining Companies in Indonesia. International Journal of Energy Economics and Policy, 10(5), 103.

https://www.idx.co.id/data-pasar/laporan-statistik/ringkasan-performa-perusahaan-tercatat/ https://www.idx.co.id/perusahaan-tercatat/laporan-keuangan-dan-tahunan/

Hunt, P. 2009. Structuring Mergers and Acquisitions: A Guide to Creating Shareholders Value. Aspen Publishers USA.

Investasi.kontan.co.id. (2020, 26 April). Peringkat bursa global: BEI urutan ke 30, masih lebih baik dari bursa IBEX Spanyol. Diakses pada 15 Oktober 2020, dari https:// investasi.kontan.co.id/news/peringkat-bursa-global-bei-urutan-ke-30-masih-lebih-baikdari-bursa-ibex-spanyol

Jensen, M. C., \& Meckling, W. H. 1976. Theory of the firm: Managerial behavior, agency costs and ownership structure. Journal of financial economics, 3(4), 305-360.

Jensen, M.C. \& Meckling, W.H. 1976. Theory of firm: managerial behavior, agency costs and ownership structure. Journal of Financial Economics. Vol. 3 No. 4. pp. 305-306.

Kontesa, Maria. 2015. Capital Structure, Profitability, And Firm Value. Whats New? Research Journal of Finance and Accounting.

Manurung, S. D., Suhadak \& Nuzula, N. F. 2014. The influence of capital structure on profitability and firm value (a study on food and beverage companies listed in Indonesia stock exchange 2010-2012 period). Jurnal Administrasi Bisnis, 7(2).

Nurkhin, A., Wahyudin, A., \& Fajriah, A. S. A. 2017. Relevansi Struktur Kepemilikan Terhadap Profitabilitas dan Nilai Perusahaan Barang Konsumsi. Jurnal Akuntansi Multiparadigma, 8(1), 35-46. 
Paminto, A., Setyadi, D., \& Sinaga, J. 2016. The effect of capital structure, firm growth and dividend policy on profitability and firm value of the oil palm plantation companies in Indonesia. European Journal of Business and Management www. iiste. org ISSN, 2222-1905.

Rahayu, S. M., \& Saifi, M. 2019. The reciprocal relationship between profitability and capital structure and its impacts on the corporate values of manufacturing companies in Indonesia. International Journal of Productivity and Performance Management.

Riaz, S. 2015. Impact of capital structure on firm's financial performance: An analysis of chemical sector of Pakistan. Journal of Poverty, Investment and Development, 12(1), 345-357.

Rohim, M., \& Syamsudin, S. P. W. S. 2019. The Effect of Ownership Structure on Firm Value with Profitability as a Moderating Variable. International Summit on Science Technology and Humanity.

Ross, S. A., Westerfield, R. W. \& Jordan, B. D. 2019. Fundamentals of Corporate Finance 12th Edition. Canadian ed. McGraw Hill.

Sekaran, U., \& Bougie, R. 2016. Research methods for business: A skill building approach. John Wiley \& Sons.

Shahid, M. N., Abbas, A., Latif, K., Attique, A., \& Khalid, S. 2020. The mediating role of board size, philanthropy and working capital management between basic corporate governance factors and firm's performance. Journal of Asian Business and Economic Studies.

Solakoglu, M. N., \& Demir, N. 2016. The role of firm characteristics on the relationship between gender diversity and firm performance. Management Decision.

Sudjana. 2010. Metode Statistika. Bandung: Tarsito.

Sugiyono. 2011. Statistika untuk Penelitian. Bandung: Alfabeta.

Sugosha, M. J., \& Artini, L. G. S. 2020. The role of profitability in mediating company ownership structure and size of firm value in the pharmaceutical industry on the Indonesia stock exchange. International research journal of management, IT and social sciences, 7(1), 104-115.

Titman, S., Keown, A. J., \& Martin, J. D. 2018. Financial management: Principles and applications $13^{\text {th }}$ Edition. United Kingdom : Pearson Education Limited.

Ullah, I., Fang, H., \& Jebran, K. 2019. Do gender diversity and CEO gender enhance firm's value? Evidence from an emerging economy. Corporate Governance: The International Journal of Business in Society.

Van Horne, J. C. \& Wachowicz, J. M. 2005. Fundamentals of Financial Management. 12th ed., Prentice Hall, London.

Vintilă, G., \& Gherghina, Ș. C. 2014. The impact of ownership concentration on firm value. Empirical study of the Bucharest Stock Exchange listed companies. Procedia Economics and Finance, 15, 271-279. 
Widnyana, I. W., Wiksuana, I. G. B., Artini, L. G. S. \& Sedana, I. B. P. 2020. Influence of financial architecture, intangible assets on financial performance and corporate value in the Indonesian capital market. International Journal of Productivity and Performance Management, Vol. ahead-of-print No. ahead-of-print. 